\title{
PENGEMBANGAN KONSERVASI WISATA BUDAYA MELALUI WISATA EVEN \\ (Studi pada Pelaksanaan Festival Reyog Nasional di Kabupaten Ponorogo)
}

\author{
Supriono \\ Prodi Pariwisata, Fakultas Ilmu Administrasi Universitas Brawijaya \\ Email: supriono fia@ub.ac.id
}

\begin{abstract}
Tourism is a variety of tourism activities and is supported by various facilities and services provided by the community, business people, the Government, and Local Governments. One of the many cultural events that are events is the Reyog Ponorogo Festival (FRN). This study aims to determine the process of developing FRN as an event tour and to find out the obstacles that occur, using descriptive qualitative methods, with data collection methods with Snowball sampling. The results showed that FRN in Ponorogo was an event tour that was able to bring in foreign and domestic tourists. Event tourism activities have an impact on the economic value of the Ponorogo community, both reyog artists and crafters (handycraft). The inhibiting factor in FRN from a technical perspective is related to the duration of the long enough implementation time (minimum of a week), sound system, participant protest. From a non-technical aspect it is more due to natural factors (rain). While the supporting factor is the awareness of reyog artists who come from outside the area, consider Reyog to be from Ponorogo, so that the implementation is automatically implemented in Ponorogo.
\end{abstract}

Keyword: Cultural Tourism, Ponorogo Reyog Festival, Development.

\begin{abstract}
ABSTAK
Pariwisata adalah berbagai macam kegiatan wisata dan didukung berbagai fasilitas serta layanan yang disediakan oleh masyarakat, pengusaha, Pemerintah, dan Pemerintah Daerah. Satu di antara sekian banyak adalah wisata budaya yang bersifat even adalah Festival Reyog Ponorogo (FRN). Penelitian ini bertujuan untuk mengetahui proses pengembangan FRN sebagai wisata even dan untuk mengetahui hambatan-hambatan yang terjadi, menggunakan metode kualitatif deskriptif, dengan metode pengambilan data dengan Snowball sampling. Hasil penelitian menunjukkan bahwa FRN di Ponorogo merupakan wisata even yang mampu mendatangkan wisatawan mancanegara maupun wisata domestik. Kegiatan wisata even berdampak pada nilai ekonomis pada masyarakat ponorogo, baik seniman reyog maupun perajin (handycraft). Faktor penghambat dalam FRN dari segi teknis adalah berkaitan dengan durasi waktu pelaksanaan kegiatan yang cukup lama (minimal seminggu), sound system, protes peserta. Dari segi non teknis lebih karena faktor alam (hujan). Sedangkan faktor pendukungnya adalah adanya kesadaran seniman reyog yang berasal dari luar daerah, menganggap Reyog berasal dari Ponorogo, sehingga secara otomatis pelaksanaannya di Ponorogo.
\end{abstract}

Keyword: Wisata Budaya, Festival Reyog Ponorogo, Pengembangan. 


\section{PENDAHULUAN}

Daya tarik wisata mempunyai kedudukan yang sangat penting pada sisi produk wisata, terutama dalam rangka menarik kunjungan wisatawan ke destinasi (Sunaryo,2013). Salah satu sumber daya tarik wisata adalah kebudayaan. Menurut Tylor dalam (Suranti, 2005:5) kebudayaan adalah keseluruhan aktivitas manusia, termasuk pengetahuan, kepercayaan, seni, moral, hukum, adat-istiadat, dan kebiasaan - kebiasaan lain. Oleh karenanya perlu adanya konservasi terhadap budaya agar budaya tersebut tetap lestari dan sekaligus dapat menjadi sumber devisa melalui kegiatan pariwisata. Upaya konservasi terhadap budaya adalah kegiatan untuk membuat budaya tetap terjaga eksistensinya meski adanya pengaruh era globalisasi. Ada banyak bentuk konservasi budaya yang bisa dilakukan, diantaranya dengan cara penulisan cerita rakyat, membuat parikan (pantun dalam bahasa jawa), hingga mengadakan festival yang mengangkat tema tentang budaya kearifan lokal. Daerah - daerah di Indonesia memiliki keanekaragaman etnik dan budaya, serta adat -istiadat yang menjadikannya sebagai daya tarik kunjungan wisatawan baik domestik maupun mancanegara, salah satunya yaitu Provinsi Jawa Timur.

Festival Reyog Ponorogo (FRN) adalah sebuah kegiatan pelestarian budaya yang sekaligus dapat menarik kedatangan wisatawan baik domestik maupun dalam negeri. Festival ini diselenggarakan secara rutin oleh Pemerintah Kabupaten Ponorogo setiap tahunnya. Adapun pelaksanaan dilakukan setiap menjelang 1 Muharam (Tahun Baru Islam). Menjadi sangat menarik mengingat Reyog Ponorogo adalah salah satu warisan budaya sekaligus ikon yang Indonesia yang telah mendunia. Tidak hanya mampu bertahan sebagai warisan budaya, akan tetapi mampu untuk mendatangkan pendapatan dari sektor wisata bagi masyarakat, daerah, dan devisa negara. Penelitian ini fokus pada ANALISIS PENGEMBANGAN KONSERVASI WISATA BUDAYA MELALUI WISATA EVEN (Studi pada Pengembangan Festival Reyog Ponorogo sebagai Wisata Event di Kabupaten Ponorogo)".

\section{Rumusan Masalah}

Rumusan Masalah dalam penelitian ini adalah:

1. Bagaimana pengembangan Festival Reyog Ponorogo sebagai wisata event di Kabupaten Ponorogo dalam rangka mendukung kegiatan pariwisata daerah?

2. Apa sajakah yang menjadi faktor pendorong dan faktor penghambat dalam penyelenggaraan Festival Reyog Ponorogo di Kabupaten Ponorogo?

\section{KAJIAN PUSTAKA}

Pengertian pariwisata menurut UU RI Nomor 10 Tahun 2009 tentang kepariwisataan ialah berbagai macam kegiatan wisata yang didukung berbagai fasilitas serta layanan yang disediakan oleh masyarakat, pengusaha, Pemerintah, dan Pemerintah Daerah. Pariwisata berhubungan erat dengan pengertian perjalanan wisata, yaitu sebagai suatu perubahan tempat tinggal sementara seseorang diluar tempat tinggalnya karena suatu alasan dan bukan untuk melakukan kegiatan yang menghasilkan upah (Suwantoro, 2004:3)

\section{Pengembangan Pariwisata}

Pengembangan adalah upaya memperluas atau mewujudkan potensi potensi, membawa suatu keadaan secara bertingkat kepada suatu keadaan yang lebih lengkap, lebih besar atau lebih baik, memajukan sesuatu dari yang lebih awal kepada yang lebih akhir atau dari yang sederhana kepada yang lebih kompleks (Ramly $\mathrm{dkk}$, 2011). Pengembangan meliputi kegiatan mengaktifkan sumber daya, memperluas kesempatan, mengakui keberhasilan dan mengintegrasikan kemajuan. Pengembangan wisata merupakan tahap lanjutan dimana setelah diadakannya sebuah perencanaan dalam pembangunan suatu obyek dan daya tarik wisata.

Menurut pendapat Marpaung (2002: 19) bahwa perkembangan kepariwisataan bertujuan memberikan keuntungan bagi wisatawan maupun bagi warga setempat. Keuntungan ekonomi dari tumbuhnya kepariwisataan dapat memberikan kehidupan yang layak bagi masyarakat setempat. Dampak lain yang dapat dirasakan oleh wisatawan dan masyarakat lokal adalah pembangunan dan perbaikan infrastruktur serta fasilitas rekreasi sebagai dampak lanjutan pengembangan pariwisata. 


\section{Kebudayaan}

Menurut Soelaeman (2007: 19) kebudayaan memiliki makna yang luas seperti peradaban, meliputi pemahaman perasaan suatu bangsa yang kompleks, meliputi pengetahuan kepercayaan, seni, moral, hukum, adat istiadat (kebiasaan), dan pembawaan lainnya yang dibawa atau diperoleh dari anggota masyarakat. Marpaung (2002: 33) berpendapat bahwa kebudayaan manusia terdiri dari kepercayaan, nilai, sikap dan kelakuan yang merupakan bagian dari masyarakat yang dilewati dari satu generasi ke generasi lain.

\section{Konservasi Budaya}

Konservasi budaya memiliki dua dimensi yang saling berkaitan. Dimensi pertama adalah dimensi kebelakang yang artinya proses perlindungan dan pengawetan terhadap kearifan lokal yang dimiliki oleh masyarakat. Dimensi yang kedua adalah dimensi kedepan yang artinya menjaga kebudayaan itu sendiri agar tetap ada. Upaya konservasi dapat berperan dalam menjaga budaya agar tetap dinamis tanpa melupakan pondasi yang telah dibangun sebelumnya. Konservasi budaya adalah sebuah upaya untuk melestarikan budaya yang dipandang sebagai warisan yang harus dijaga dan dilindungi agar tetap ada dan dinamis mengikuti perkembangan zaman.

\section{METODE PENELITIAN}

Pada penelitian kali ini, peneliti menggunakan penelitian deskriptif dengan pendekatan kualitatif. Menurut Nazir (2005:54), metode deskriptif adalah suatu metode dalam meneliti status sekelompok manusia, suatu objek, suatu set kondisi, suatu sistem pemikiran, ataupun suatu kelas peristiwa pada masa sekarang.

Metode deskriptif ini dijalankan dengan cara melakukan survei di lokasi penelitian. Metode survei adalah penyelidikan yang dilakukan untuk memperoleh fakta-fakta dari gejala-gejala yang ada dan mencari keterangan secara faktual, baik tentang institusi sosial, ekonomi, atau politik dari suatu kelompok ataupun suatu daerah (Nazir, 2005).

Pengambilan sampel sumber dan data dilakukan secara purposive dan snowball, teknik pengumpulan data dilakukan dengan triangulasi (gabungan) analisis data bersifat induktif atau kualitatif, dan hasil penelitian kualitatif lebih menekankan pada makna daripada generalisasi (Sugiyono, 20105).Penelitian ini menggunakan cara observasi langsung di lapangan untuk menjawab rumusan masalah yang telah dibuat. Selain itu, pemilihan pendekatan ini bertujuan untuk mendapatkan data yang lebih kaya makna daripada sekedar data yang berbentuk angka.

\section{HASIL PEMBAHASAN}

\section{Sejarah Festival Reyog Nasional}

Grebeg Suro oleh masyarakat Ponorogo dilaksanakan dalam bentuk pesta rakyat. Pesta rakyat disini diantaranya mengandung unsur Seni dan tradisi seperti Festival Reog Nasional, Kirab Pusaka dan Pawai Lintas Sejarah, serta Larungan Risalah Doa di Telaga Ngebel. Grebeg Suro merupakan acara yang diagendakan oleh pemerintah Ponorogo setiap tahunnya,acara ini dilaksanakan setiap tanggal 1 Muharram (1 Suro pada tahun Jawa) atau beberapa hari menjelang malam 1 suro.

Selanjutnya Pada tahun 1995 bupati Ponorogo ganti pak Markum Singodimedjo beliau ingin mengangkat Festival Reyog itu dipanggungkan dan skalanya yang awalnya Lokal ponorogo di naikkan menjadi skala Nasional.

\section{Festival Reyog Nasional Sebagai Wisata Budaya}

Konsepnya jelas bahwa FRN itu oleh pemerintah Ponorogo dikemas dengan sedemikian rupa agar menarik dan bisa dijadikan wisata budaya. Dimana dulu pada waktu pelaksanaan pertama kurang begitu menarik selanjutnya dikembangkan dari tahun ke tahun sehingga FRN bisa menjadi salah satu destinasi wisata budaya, dan hal tersebut berimbas kepada perekonomian.

Unsur wisata budaya yang dapat menarik wisatawan antara lain: Bahasa; Masayarakat; Kerajinan tangan; Makanan; Musik dan Kesenian; Sejarah; Cara Kerja; Agama; Arsitektur bangunan; Sistem pendidikan. Dalam kaitannya dengan hal tersebut pelaksanaan Festival Reyog Nasional mengandung unsur kesenian, sejarah, dan kerajinan tangan. Pada tujuan untuk mengembangkan budaya asli Ponorogo dan terus melestarikannya. Tujuan pelaksanaan FRN ternyata tidak sekedar dalam rangka melestarikan saja, lebih jauh kegiatan FRN juga mampu memberikan dampak positif terhadap perekonomian masyarakat ponorogo. Dengan adanya kegiatan wisata even ini, maka seni budaya ponorogo semakin dikenal oleh masyarakat luas, baik dalam maupun luar 
negeri. Banyak wisatawan dalam maupun luar negeri yang terus berdatangan dan ketika pulang selalu membutuhkan cindera mata berupa pernak-pernik yang berhubungan dengan Seni Reyog Ponorogo.

Masayarakat sangat diuntungkan dengan kondisi tersebut. Mereka membuat kerajinan tangan (handycratf) yang dijual kepada para wisatawan yang datang. Tidak hanya sekedar yang murah, yang mahal pun tetap dibuat dan mampu terjual. Hal tersebut membuat profesi masayarakat tidak hanya tergantung pada pertanian, tetapi ada tambahan dari membuat kerajinan tersebut. Jadi wisata budaya FRN justru berdampak positif bagi masyarakat ponorogo.

\section{Tolok Ukur Keberhasilan dalam Penyelenggaraan FRN}

FRN dari tahun ke tahun selalu mendapatkan animo yang sangat tinggi dari masyarakat Ponorogo maupun di luar ponorogo. Hal ini terbukti, sejak diselenggarakan pertamakali tahun 1998, masyarakat tidak pernah bosan dengan keberadaannya, walaupun sebenarnya konsep FRN selalu sama setiap tahunnya. Tidak pernah sepi dari penonton dan pengunjung yang meramaikan setiap kali penyelenggaraan.

Berbagai macam tolok ukur yang dijadikan acuan penyelenggaraan FRN ini berhasil atau tidak. Diantaranya adalah:

\section{Peserta Banyak}

Banyaknya peserta (grup) Reyog yang ikut andil dalam pementasan merupakan tolok ukur keberhasilan yang pertama. Semakin banyak peserta berarti membuktikan bahwa reyog merupakan sebuah festival yang sangat ditunggu oleh para seniman reyog. Tidak hanya seniman saja, para penikmat pertunjukkan (wisatawan) juga lebih suka ketika banyak grup reyog yang tampil dikarenakan akan banyak keanekaragaman koreografi pertunjukkan yang berbasis seni reyog. Walaupun pada umumnya memiliki dasar gerak yang sama, tetapi bagi para seniman yang paham akan tahu, bahwa karakter masing-masing daerah grup reyog memiliki ciri khas berbeda. Seperti diketahui, reyog memang berasal dari Kabupaten Ponorogo, akan tetapi reyog telah menyebar ke seluruh penjuru tanah air dan dunia. Sehingga keanekargaaman gerak yang dipengaruhi seni reyog berada sangat kental sekali. Misal, grup reyog yang berasal dari Surabaya sering memasukkan unsur gerak tari remo (asli kesenian Surabaya) dalam sendra tari Reyog Ponorogo. Begitu juga dari Banyuwangi sering memasukkan unsur Tari Gandrung.

2. Peserta memenuhi standart

Standar yang dimaksud di sini adalah tatkala peserta / grup reyog yang tampil dalam kegiatan ini dapat memenuhi pakem (aturan) yang ditentukan. Rangkaian tari dalam FRN telah ditentukan, yaitu menceritakan sejarah tentang proses sejarah Prabu Klonosewandono yang berasal dari Kerajaan Bantarangin ingin melamar Dewi Songgolangit di Kerajaan Kediri. Mengirim utusan bernama Patih Pujanggaanom (lebih dikenal Bujangganong dalam pertunjukkan reyog), namun gagal karena dihadang oleh Prabu Singobarong dari Kerajaan Lodaya (Blitar) yang berwujud wajah Harimau dan di atas kepalanya ada Merak. Akhirnya, Prabu Klonosewandono turun tangan sendiri disertai dengan para prajurit berkuda (lebih dikenal Jathil dalam pertunjukkan reyog). Singkat cerita, Prabu Singobarong dapat dikalahkan oleh Prabu Klonosewandono.

Standar yang dimaksudkan di sini adalah harus sesuai dengan urutan sejarah terjadinya reyog. Setiap grup standarnya sama. Hanya saja untuk proses menjadi juara dan tidak adalah berdasarkan keindahan ragam gerak dalam sendra tari tersebut, keindahan penyajian musik pengiring, dan sebagainya.

3. Tidak ada kendala teknis

Kendala teknis yang dimaksud di sini adalah yang berhubungan dengan operasional di lapang pada saat pelaksanaan FRN. Misal, peralatan tari (Dhadak Merak, Instrumen musik), sound system, kekurangan dana,dan penundaan jadwal karena hal tertentu. Namun hal tersebut dapat diantisipasi sebelum pelaksanaan.

Adapun kendala non teknis yang bersifat dari alam yang sulit diprediksi adalah terjadi hujan pada saat pelaksanaan. Apalagi pelaksanaan dilaksanakan malam hari. Ini menghambat proses pelaksanaan karena pelaksanaan dilaksanakan outdoor. Berada di alun-alun utama Ponorogo. Kondisi tersebut sekarang telah diantisipasi dengan menyediakan tenda untuk panggung sendra tari. Walaupun begitu tetap saja terganggu, terutama di tribun penonton. Karena tidak ada tenda di sana, sehingga 
penonton akan berkurang yang berdampak pada penjualan tiket berkurang.

4. Peserta menang atau kalah bisa puas

FRN bersifat kompetisi, ada yang menjadi juara dan tidak menjadi juara di dalam pagelaran ini. Satu di antara tolok ukur keberhasilan adalah apabila peserta yang menjadi pemenang maupun tidak menjadi pemenang merasa puas. Oleh karenanya, diawal panitia selalu menyampaikan, bahwa pada hakekatnya FRN adalah sebuah pesta perayaan Reyog agar mampu mengenal grup reyog satu dengan yang lainnya dari seluruh penjuru tanah air, bahkan dunia.

Pada awalnya, dulu memang banyak sekali protes yang terjadi dari peserta yang tidak menjadi juara. Namun dengan adanya pendekatan persuasif melalui diskusi, akhirnya masalah tersebut daoat diselsesaikan. Untuk sekarang pada umumnya para peserta merasa puas dengan kegiatan FRN. Terlepas mereka menang atau tidak menang menjadi juara. Mereka mulai menyadari bahwa esensi dari penampilan di pentas adalah karena ingin mengekspresikan hasil karya tari, bukan hanya sekedar nilai (juara). Kalaupun juara, itu merupakan bonus. Oleh karenanya, sampai saat ini tetap saja FRN selalu dihadiri oleh peserta dari berbagai macam daerah.

\section{FRN dibandingkan dengan Festival Reyog di tempat lain}

Festival Reyog, ternyata tidak hanya terselenggara di Ponorogo saja. Festival yang sama persis juga diselenggarakan. Antara lain:

1. Festival Reyog se Kabupaten Wonogiri Jawa Tengah

2. Semarak Singo Barong di Solo Jawa Tengah

3. Festival Reyog Jember/Festival Reyog Tapal Kuda di Jember - Jawa Timur

4. Festival Singo Barong di Batu - Jawa Timur. Namun Festival tersebut tidak dianggap pesaing bagi FRN. Justru keberadaannya semakin mendukung FRN di Ponorogo, karena biasanya para juara di kegiatan tersebut, selanjutnya akan dikirim ke FRN juga. Ini berarti malah membantu pihak penyelenggara untuk menyaring standar kualitas grup reyog yang akan tampil di FRN.

Selain itu, kelebihan dari FRN dibandingkan festival reyog di berbagai daerah adalah karena nilai "prestisius"nya. Sehingga ada anggapan, jika seorang belum tampil di alun
- alun utama Ponorogo dalam rangka FRN, maka kurang sempurna sebagai seorang seniman reyog. Apalagi FRN memperebutkan piala Presiden, sedangkan yang lainnya hanya piala kepala daerah.

Tidak hanya sudut pandang prestisiusnya, tetapi dari segi panggung dan pendukungnya (lighting, sound system, dan sebagainya) lebih mewah dibandingkan dengan Festival di daerah. Jika di daerah panggungnya bersifat non permanen dan relatif lebih kecil, maka di Ponorogo sebaliknya. Panggungnya sangat luas dan sifatnya permanen. Adapun peralatan pendukung dibuat semaksimal mungkin kinerjanya. Panitia harus mengeluarkan dana yang besar untuk hal ini.

Selain memiliki keunggulan, kelemahan dari FRN adalah durasi yang cukup panjang dalam pelaksanaan. Minimal seminggu. Hal ini berakibat, grup reyog yang berasal dari luar daerah harus menyediakan anggaran besar untuk akomodasi penginapan dan konsumsi selama tinggal di Ponorogo agar mampu mengikuti kegiatan sampai selesai. Setiap grup biasanya terdiri dari minimal 50 orang. Anggaran yang besar ini tidak sebanding dengan hadiah yang didapatkan oleh peserta, walaupun grup tersebut juara pertama. Karena anggaran disediakan tidak hanya pada saat berada di Ponorogo saja, tapi pada saat proses latihan, biasanya 40 hari sebelum hari $\mathrm{H}$ tampil.

\section{KESIMPULAN DAN SARAN Kesimpulan}

1. Pengembangan Festival Reyog Nasional (FRN) di Ponorogo merupakan wisata even yang mampu mendatangkan wisatawan mancanegara maupun wisata domestik. Kegiatan wisata even berdampak pada nilai ekonomis pada masyarakat ponorogo, baik seniman reyog maupun perajin (handycraft) segala atribut yang berhubungan dengan reyog.

2. Faktor penghambat dalam FRN dari segi teknis adalah berkaitan dengan durasi waktu pelaksanaan kegiatan yang cukup lama (minimal seminggu), sound system, protes peserta. Dari segi non teknis lebih karena faktor alam. Bisanya hujan. Sedangkan faktor pendukungnya adalah Reyog berasal dari Ponorogo, sehingga secara otomatis pelaksanaannya di Ponorogo. Kesadaran dari para seniman Reyog di luar Ponorogo yang setiap tahunnya selalu mengikuti acara FRN sebagai peserta. 


\section{Saran}

1. Penyelenggara FRN terus mampu membenahi kekurangan-kekurangan bersadasarkan pelaksanaan tahun sebelumnya. Antara lain, tempat penonton belum bisa terlindung dari hujan, jika pelaksanaan pad saat musim hujan;

2. Hadiah yang berupa uang bisa diperbesar, minimal sesuai dengan biaya proses latihan dengan biaya akomodasi yang dikeluarkan oleh peserta FRN.

\section{DAFTAR PUSTAKA}

Marpaung, Parlindungan, 2002, Analisis Perubahan Nilai Sosial Budaya Dan Pengaruhnya Terhadap Pembangunan Wilayah Di Kecamatan Pangururan Kabupaten Tapanuli Utara, Program Pasca Sarjana USU, Medan

Nazir, Mohammad. 2005. Metode Penelitian. Cetakan Pertama. Jakarta: Ghalia Indonesia.

Ramly, Mansyur dkk. 2011. Pedoman Pelaksanaan Pendidikan Karakter (Berdasarkan Pengalaman Satuan Pendidikan Rintisan). Jakarta: Kementrian Pendidikan Nasional Badan Penelitian dan Pengembangan Pusat Kurikulum dan Perbukuan.

Soelaeman, Munandar.2007. Sosiologi:Suatu Pengantar .Jakarta:PT Raja Grafindo Persada.
Sugiyono. 2010. Metode Penelitian Pendidikan Pendekatan Kuantitatif, kualitatif, dan R\&D. Bandung: Alfabeta

Sunaryo, Bambang, 2013 Kebijakan Pembangunan Destinasi Pariwisata : Konsep dan aplikasinya di Indonesia, Yogyakarta; Gava Media.

Suranti, Ratna 2005, Pariwisata Budaya dan Peran serta Masyarakat, Workshop Wisata Budaya Bagi Kelompok Masyarakat Propinsi DKI Jakarta, 12 Juli 2005

Suwantoro, Gamal. 2004. Dasardasar Pariwisata. Penerbit Andi Yogyakarta

UU RI Nomor 10 Tahun 2009 Tentang Kepariwisataan 